\title{
Transport conditions of mountain-surging glaciers as recorded in the micromorphology of quartz grains (Medvezhiy Glacier, West Pamir)
}

\author{
Agnieszka Muzińska \\ Faculty of Geography and Regional Studies, University of Warsaw, \\ Krakowskie Przedmieście 30, 00-927 Warszawa, Poland; \\ e-mail: a.muzinska@uw.edu.pl
}

\begin{abstract}
In order to reproduce the conditions under which sediments were transported in surging glaciers, samples were taken from the margin and foreland of the surge Medvezhiy Glacier situated in West Pamir (Tajikistan). They were subjected to an analysis of rounding and frosting of quartz sand grains $(0.8-1.0 \mathrm{~mm})$ and of grain surface micromorphology under scanning electron microscope (SEM). Results obtained showed intense chemical weathering occurred in the majority of quartz grain surfaces, marked in the form of etching and precipitation. Frequencies of microstructures of glacial origin were low; individual microstructures were visible on single grains. A predominance of the crushing process over abrasion in transformation of quartz grains was noted. The commonest microstructures connected with a surge-glacier environment were large and small conchoidal fractures. However, grains with primary features not connected with a glacial environment were equally common. The majority of the grains examined showed features of multiple cycles of mechanical and chemical weathering forming a microtexture under various conditions (overprinting). Common features of grains from surging glaciers are also breakage blocks of $>10 \mu \mathrm{m}$, which depend of the phase of separation of the grain from the rock or on thermal changes in the glacier's foreland.
\end{abstract}

Keywords: glacier surge; SEM; abrasion; crushing; chemical weathering; frost weathering

\section{Introduction}

Glacier surges are a kind of pulsating flows of ice in a glacier, which are characterised by internal release of sudden bursts in flow velocity (Meier \& Post, 1969; Clarke, 1987; Raymond, 1987). Benn \& Evans (1998) defined the surges as a periodic phenomenon which lasts between a few years to a few hundred years, and in which one can distinguish two phases: an active phase and a quiescent one. The maximum velocity of flowing ice in an active surge is equal to or greater than ten times that reached prior to the surge (Raymond, 1987; Paterson, 1994; Benn \& Evans, 1998). Surges differ greatly and are rarely recorded. It is estimated that they appear in less than $1 \%$ of the total number of the world's glaciers (Murray et al., 2003). Some surges are minor and short-term, while others are extreme events in the movement of a glacier and they transform its margin and foreland completely (Dolgushin \& Osipova, 1975).

Examining glacier surges provides information on the internal processes ruling the glacier system (Embleton \& King, 1975) - the mechanisms of ice flow, the conditions on the glacier's bed and the impact of climate on glaciers (Benn \& Evans, 1998). Moreover, examining glacier surges, especially in populated areas (such as Pamir, Karakorum, Hindu Kush) may have a much wider significance. The International Centre for Integrated Mountain Development (ICIMOD 2011) reported on glacier surges among the causes of glacial lake outburst 
floods (GLOF) which endanger human lives and economy. Understanding the mechanisms of this dramatic glacial advance allows people to predict and prevent the consequences of the floods in endangered areas.

The aim of Kenig's research (1980) in Spitsbergen and that by Rose and Hart (2007) in Norway was the micromorphological character of sediments of surging glaciers. The results of these analyses are a valuable source of knowledge on the intensity and type of processes occurring inside a glacier during a surge.

The object of my research was the micromorphology of sediments transformed by the glacier surges including: (1) determining the conditions during transportation of the material on the glacier's bed, (2) determining the sediment source, (3) the degree of their transformation quartz sand grains during transport in the glacial environment, (4) evaluation of the impact and intensity of post-sedimentary processes affecting the grains, and (5) establishment of characteristics of the morphological structure of quartz grain surfaces from surging glaciers.

\section{Study area}

Field work was conducted on the foreland and margin of the Medvezhiy Glacier located in West Pamir, Tajikistan (Fig. 1A, B), in September 2012. Medvezhiy Glacier is a valley glacier which flows down the western slopes of the Akademiya Nauk Range into the Vanj Valley. The summits surrounding the ice tongue are up to 5,800-6,000 $\mathrm{m}$ a.s.l. (Dolgushin \& Osipova, 1975). Length and surface of Medvezhiy Glacier fluctuate depending of the glacier's surges which occur regularly, every 10 to 14 years on average (Dolgushin \& Osipova, 1975).
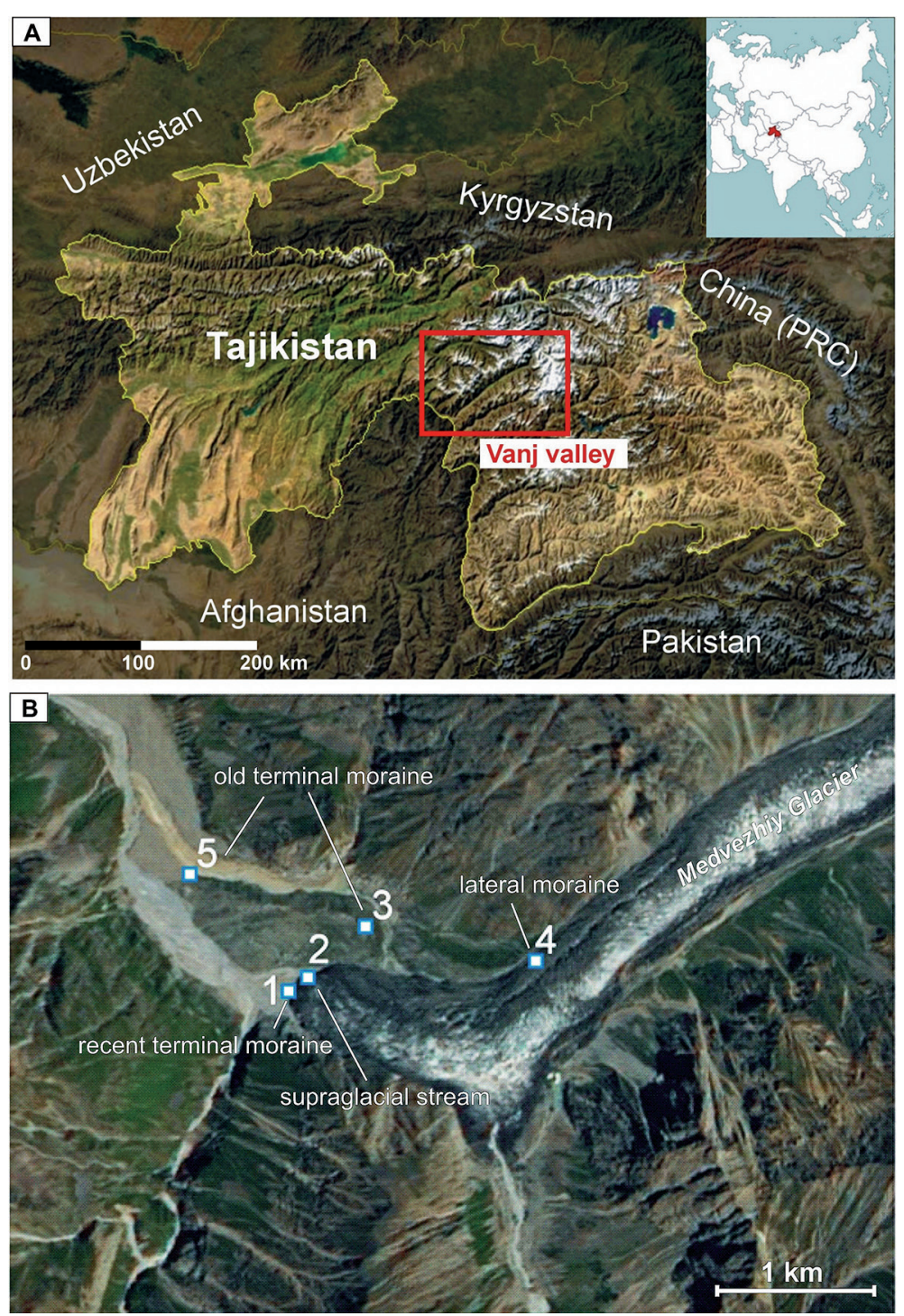

Fig. 1. Study area: A - Vanj valley, Pamir, Tajikistan (satellite imagery from NASA World Wind, modified by author); B - Location of sampling places (www. earthexplorer.usgs.gov). 
In the quiescent phase, the glacier has a length of up to 13 kilometres, with an average ice tongue width of 500 metres (Zabirov, 1955; Dolgushin \& Osipova, 1975). The ice tongue of the Medvezhiy Glacier flows down from the firn field in a 600-metre and a 45-degree inclined icefall, while the average slope on the last 8 kilometres of the tongue does not exceed 7-8 degrees (Dolgushin \& Osipova, 1975). During my research, the glacier's snout was located at 2,915 $\mathrm{m}$ a.s.1., following the 2011 surge.

\subsection{Review of Medvezhiy Glacier surges}

Medvezhiy Glacier surges are characterised by an exceptional regularity, as they occur every 10 to 14 years (Fig. 2). The most commonly registered phenomenon of this kind were the 1937 and 1951 surges (Dolgushin \& Osipova, 1975). The first surge of the Medvezhiy Glacier that was described in the scientific literature took place in 1963. Based on aerial photographs and measurements taken in the field, changes in glacier morphology, the velocity of the ice flow and glacial mass balance were inferred (Dolgushin \& Osipova, 1975). The greatest velocity of the glacier's snout during this transgression was around 100 metres per day. In two months the snout had moved by over 1,600 metres (Dolgushin \& Osipova, 1975). The transgression led to the creation of an ice dam and a reservoir on the upper segment of

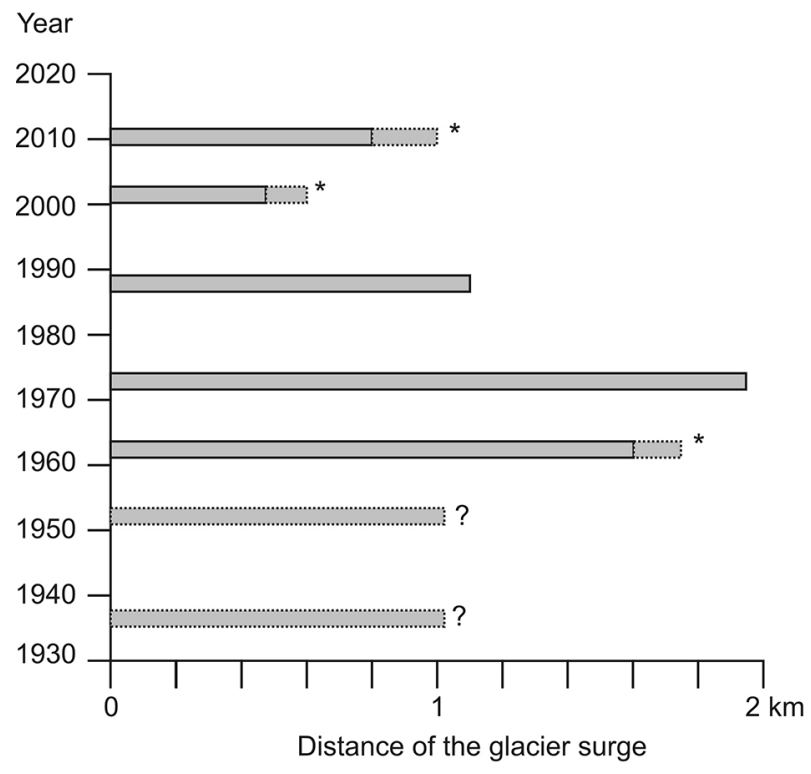

Fig. 2. Frequency and scale of snout's advances of Medvezhiy Glacier surges, based on Dolgushin \& Osipova (1975), Kotlyakov et al. (1997), Novikov (2002) and personal observations.

* - estimated value of snout's advances; ? - lack of data on the scale of snout's transgression. the valley, and breaching of the dam caused a glacial flood with serious consequences (Dolgushin \& Osipova, 1975; Nowikov, 2002). The next surge was registered in 1973, when the Medvezhiy Glacier flowed down through the valley once again, blocking the Abdukagor River and the estimated snout's transgression was 1,950 metres long (Kotlyakov et al., 1997). The episodes in 1988-1989 and in 2001 were not such great transgressions. Medvezhiy Glacier's last surge occurred at the turn of the months of June and July 2011. Based on aerial photographs and measurements taken in the field it was estimated that the snout had moved by 800 to 1,000 metres.

\section{Methods}

The rounding and frosting of sand quartz grains $(0.8-1.0 \mathrm{~mm})$ were examined on the basis of the method by Cailleux (1942), with subsequent modifications of Goździk (1980) and Mycielska-Dowgiałło \& Woronko (1998), and was carried in order to describe the processes in glacial environment thoroughly. It was then supplemented by a detailed analysis of microstructures on the quartz grain surface (0.8-1.0 mm) under SEM (Whalley \& Krinsley, 1974; Mahaney et al., 2001; Mahaney, 2002).

\subsection{Samples}

Five samples were taken from the margin and foreland of Medvezhiy Glacier: 1 - the recent terminal moraine, created during the 2011 surge; 2 - the supraglacial stream flowing from the glacier's snout; 3 - the ridge of the old terminal moraine; 4 - the glacier's old lateral moraine; 5 -the bottom part of the old terminal moraine (Fig. 1B). Examinations were based on the collection of just a single sample at each point, which is explained by the difficult conditions in the area. There are numerous crevasses on the glacier's snout after the last surge in 2011, and Tajik law forbids the transport of minerals from the Pamir Mountains.

Samples 3 and 5 come from a moraine of over $c$. 100 years old, which is corroborated by its size, the presence of flora and the fact that the moraine can be seen in archive aerial and satellite photographs and pictures. Samples 1, 3 and 5 provide data on transformation of the quartz grain surface caused by processes in environment of a surging glacier. Samples 2 and 4 allow to supplement data on the characteristics of the source material from the valley's slopes, because these were transported pas- 
sively. Samples 1, 3, 4 and 5 were collected from a depth of $10-15 \mathrm{~cm}$.

\subsection{Rounding and frosting of sand quartz grains}

The method of assessing rounding and frosting of quartz grains $(0.8-1.0 \mathrm{~mm})$ follows Cailleux (1942), as modified by Goździk (1980) and Mycielska-Dowgiałło \& Woronko (1998). Between 100 and 120 randomly selected grains were counted in each sample. Before the analysis all samples were rinsed with a $10 \%$ hydrochloric acid $(\mathrm{HCl})$, then they were washed with distilled water and left to dry (Mycielska-Dowgiałło \& Woronko, 1998). This analysis combines the degree of roundness of grains by a 9-degree classification of grain shape by Krumbein (1941) with their surface. Seven rounding and frosting classes were distinguished in the sand quartz grains: NU - fresh, with sharp all edges and no traces of processing in current environments e.g. aeolian or fluvial; C - cracked, with over $30 \%$ loss of the original grain surface, it can represent different environments, but they are mostly characteristic of glacial or periglacial environments; EL - very well-rounded with smooth and shiny surface, high-energy, aquatic environments; $\mathrm{EM} / \mathrm{EL}$ - shiny, moderately rounded, high-energy, aquatic environments; RM - very well-rounded, mat surface, aeolian; EM/RM - moderately rounded mat grains, aeolian environment and OTHERS - not fitting any other group, with surface formed by chemical weathering, present as precipitation or etching (Mycielska-Dowgiałło \& Woronko, 1998). Based on the results of the analysis, grain origin was established, together with the type and intensity of processes which formed the grain's surface. Results were presented as histograms of percentages of a certain grain type in each sample.

\subsection{Micromorphology of quartz grains under SEM}

Twenty to twenty-five grains were selected from each sample to be examined under SEM, type JSM6380 LA, coupled with an EDS microprobe. SEM analysis of the microstructures on quartz grain surfaces was carried out in order to obtain more detailed data on the genesis and conditions during transport, deposition of sediments, and post-sedimentary processes which formed the quartz grain surface (Krinsley \& Doornkamp, 1973; Whalley
\& Krinsley, 1974; Whalley \& Langway, 1980; Mahaney, 1990, 1995, 2002; Traczyk \& Woronko, 2010). The investigation was divided into two stages. The first one was carried out at c. 30x magnification, to determine the diversity of microrelief (low/medium/high) and sharpness of grain edges (rounded or sharp). The second stage consisted of the identification of microstructures on the grain surfaces according to Mahaney (2002), extended to microstructures as described by Helland \& Holmes (1997) and Woronko (2012). Microstructures were identified at a 1,000x magnification. Traces of abrasion, crushing, chemical and mechanical weathering were noted on the grain surfaces.

Moreover, microstructures were identified that are related to frost weathering: (1) breakage blocks $(>10 \mu \mathrm{m}$ and $<10 \mu \mathrm{m})$, which occur on rounded edges, inside of depressions and crevasses; (2) cracks along crevasses and (3) fresh conchoidal fractures (Woronko \& Hoch, 2011). Based on the number of microstructures on the surface of individual quartz grains related to frost weathering the ST index of degree of weathering was calculated. Its scale has four points, from 0 to 3 , as follows: 0 - no visible traces of frost weathering; 1 - one or two microstructures caused by frost weathering visible; 2 - three to ten visible microstructures caused by frost weathering; 3 - frost weathering visible on most of the grain surface. The sum of the ST index for individual grains divided by the number of particles used in the analysis made it possible to calculate the dimensionless frost action index (FAI). It changes the value in the range from 0 to 3 (Woronko \& Hoch, 2011).

\section{Results and interpretation}

\subsection{Cailleux analysis}

The results of the analysis of rounding and frosting of quartz grains $(0.8-1.0 \mathrm{~mm})$ based on the method described by Cailleux (1942), with later modifications by Goździk (1980) and Mycielska-Dowgiałło \& Woronko (1998), show that all samples are dominated by grains classified as OTHER (Fig. 3A; Table 1). The frequency of OTHER grains changes from $39 \%$ in sample 1 (the recent terminal moraine) to $81 \%$ in sample 4 (the old lateral moraine) (Fig. 1B; Table 1). The surface of most of these grains was shaped by intensive chemical weathering (amorphous precipitation). The next commoner type was cracked grains (C). A large amount was noted in samples $3(30 \%)$ and $5(39 \%)$. Whereas in sample 4 its value does not exceed 20\% (Table 1). 

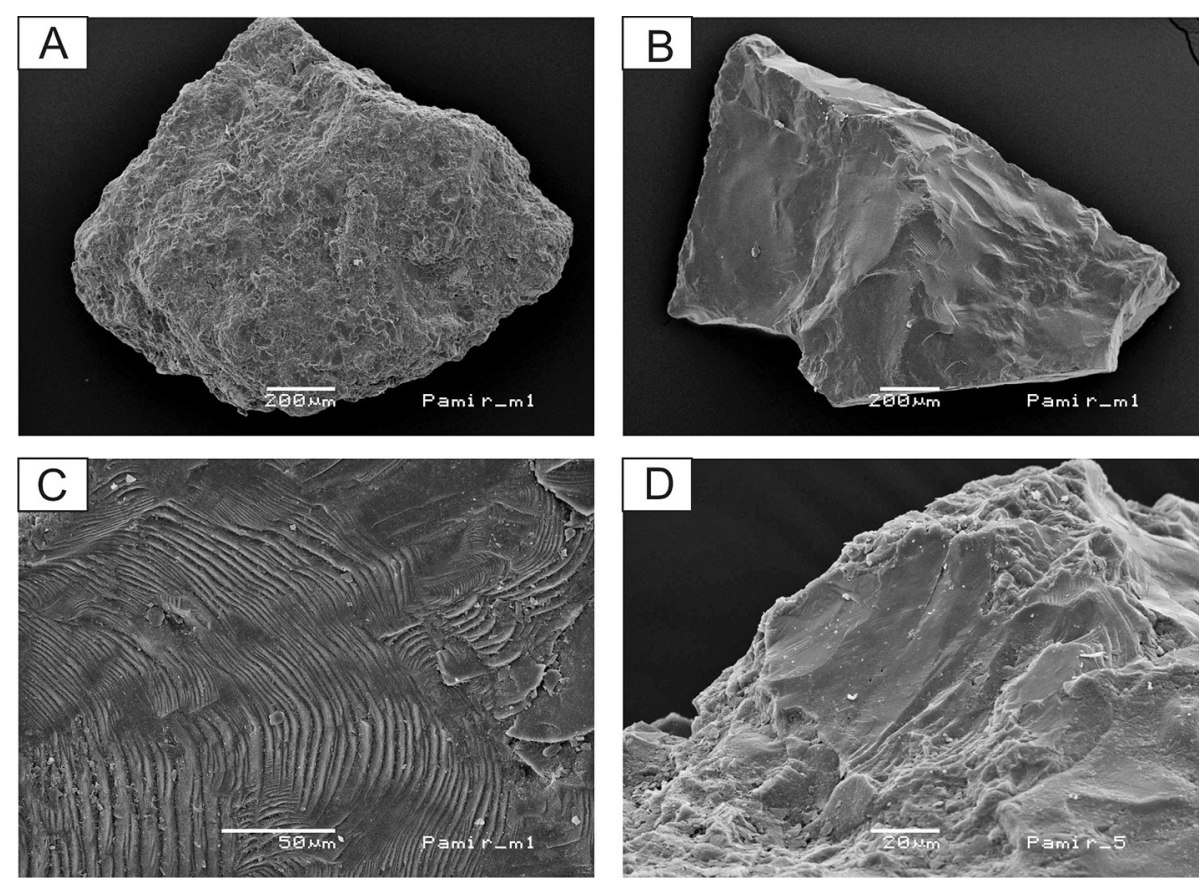

Fig. 3. A - OTHER type of grain (sample 1); B - High relief of NU type of grain (sample 1); C - Arc-shaped steps (sample 1); D - Conchoidal fracture $>10 \mu \mathrm{m}$.

Much rarer than the above-mentioned there are grains completely fresh and of the angular type, NU (Fig. 3B). Their percentage does not exceed 10\%, except in sample 1, where the amount of these grains (NU) exceeded 20\%. In samples 1 and 3 there were identified shiny, moderately rounded grains (type EM/EL), typical of high-energy beach or fluvial environments (Mycielska-Dowgiałło \& Woronko, 1998). Their frequency was more than $10 \%$ in sample 1. Shiny, well-rounded grains (EL), mat very well-rounded (RM) and mat moderately rounded

Table 1. Results of roundness and frosting analysis of quartz grains (0.8-1.0 mm) following Cailleux (1942), with modifications by Goździk (1980) and Mycielska-Dowgiałło \& Woronko (1998).

\begin{tabular}{lrrrrr}
\cline { 2 - 6 } & \multicolumn{5}{c}{ Samples (percentage of grains) } \\
\hline Type of grain & 1 & 2 & 3 & 4 & 5 \\
\hline NU & 25 & 5 & 2 & 0 & 10 \\
EL & 0 & 0 & 0 & 0 & 0 \\
RM & 0 & 0 & 0 & 0 & 0 \\
EM/EL & 11 & 0 & 1 & 0 & 0 \\
EM/RM & 0 & 0 & 0 & 0 & 0 \\
OTHER & 39 & 71 & 68 & 81 & 52 \\
C & 25 & 24 & 30 & 19 & 39 \\
\hline
\end{tabular}

grains (EM/RM) were not found in any of the samples (Table 1).

\subsection{Micromorphology of quartz grains under SEM}

Most grains were medium and high relief in all samples (Fig. 3B). They had diverse microrelief and sharp edges. High-relief grains made up high percentage of the sediments from 2011 terminal moraine (sample $1-80 \%$ ) and from the bottom part of the old terminal moraine (sample 5-70\%).

\subsubsection{Microstructures caused by chemical weathering}

In all samples, on most grains microforms were observed that were caused by chemical weathering. They resulted from intensive, selective etching and enhancing the defects in quartz structure. The frequency of grains with etched microstructures in samples 1-4 exceeds $90 \%$, while in sample 5 it is $55 \%$ (Fig. 4). Among them the commonest was the dissolution surface and the rarest were solution crevasses and solution pits. At the same time surfaces were observed that formed as a result of amorphous precipitation. In many cases both processes, etching and amorphous precipitation, occupied most of grain surfaces and they were responsible for the edge rounding of grains. Also, a frequent presence of microforms caused by chemical weathering is 
closely linked with a high percentage of fragments of older, pre-weathered surfaces which were present on over $95 \%$ of grains analysed.

\subsubsection{Microstructures caused by crushing and abrasion}

On quartz grain surfaces effects of crushing and abrasion were visible (Mahaney, 2002). Encountered regularly were large conchoidal fractures $(>10 \mu \mathrm{m})$ caused by crushing (Sharp \& Gomez, 1986) (Fig. 3D). They were found on $80-100 \%$ of the grains of each sample (Fig. 5). Although these large conchoidal fractures were observed on such a large number of particles, they existed in the form of individual microstructures of the surface of a single grain. In most cases the surface of the conchoidal fractures was characterised by a weak morphological structure, flat, without any additional microstructures such as linear and microsteps or arcshaped steps (Fig. 3C). The surface of the conchoidal fractures was not fresh in all cases. Parts of them were old and coated by amorphous silica. The last of the microstructures was listed on the $60-90 \%$ of grains, but mostly as a single trace. The rarest in the samples examined were radial fractures $(5-10 \%)$.

Microstructures caused by abrasion (Fig. 6) were small conchoidal fractures $(<10 \mu \mathrm{m})$ (Sharp \& Gomez, 1986). On the surface of the grains examined they were rarer than those caused by crushing (Figs. 5, 6). Small conchoidal fractures predominate; in addition, they were observed on the rounded edges of grains as well as on the sharp edges of larger conchoidal fractures $(>10 \mu \mathrm{m})$. The effect of abrasion created more isometric grains (Rose \& Hart, 2007). Similar to large conchoidal fractures the frequency of small ones was very low on the surface of individual grains. In every sample a few microgrooves were noted, both straight grooves (from $5 \%$ in sample 4 to $50 \%$ in sample 1 ) and curved grooves (from $10 \%$ in samples 3 and 5 to $40 \%$ in sample 1) (Fig. 6). Extremely rare are chattermark microstructures. In sample 3 they were not found and in samples 1 and 5 their frequency does not exceed $25 \%$.

Table 2. Frequency of occurrence of overprinted surfaces in individual samples.

\begin{tabular}{|c|c|c|c|c|c|}
\hline Number of sample & 1 & 2 & 3 & 4 & 5 \\
\hline $\begin{array}{l}\text { Overprinted surfaces } \\
\text { in the sample [\%] }\end{array}$ & 45 & 10 & 60 & 32 & 50 \\
\hline
\end{tabular}

Table 3. The FAI value.

\begin{tabular}{lccccc} 
Number of sample & 1 & 2 & 3 & 4 & 5 \\
The FAI value & 0.65 & 0.75 & 0.65 & 0.79 & 0.95 \\
\hline
\end{tabular}

The grains which were characteristically overprinted surfaces were commonest in samples 1 $(45 \%), 3(60 \%)$ and $5(50 \%)$. This feature expresses the multiple cycles of processing which every grain passed through (Table 2).

\subsubsection{Microstructures caused by mechanical weathering in situ}

The most frequent microstructures connected to mechanical weathering in situ were breakage blocks $>10 \mu \mathrm{m}$. The frequency of their occurrence varied between $80 \%$ (sample 3) and $95 \%$ (samples 1 and 2). Also small conchoidal fractures $<10 \mu \mathrm{m}$ and small breakage blocks $<10 \mu \mathrm{m}$ were observed on sharp features of grains.

\subsubsection{Frost action index (FAI)}

The frost action index (FAI) for individual samples varied from 0.65 to 0.95 . Sample 5 collected from the bottom part of the old terminal moraine had the highest value. The lowest value was recorded in the moraine number 1 (Table 3). Marks of frost action were noticed mainly on sharp features of grains. Most often microforms ascribable to frost action processes were breakage blocks and small conchoidal fractures (Fig. 7A, B).

\section{Discussion}

\subsection{Effect of surging Medvezhiy glacier transport on quartz grain surface}

The micromorphology of the quartz grain surfaces analysed under SEM yields data on transport conditions in surging glaciers, allowing researchers to estimate the influence of individual processes on the texture of the grains. Mahaney (2002) reported that on the quartz grains representing the glacial environment can be found a broad spectrum of microstructures, including multiple fracture faces, V-shaped percussion cracks, shock-melted textures and a range of dissolution microfeatures. These could result from weathering, occurring e.g. during a pre-existing interglacial, prior to glacial entrainment to the ice. Quartz grains, which were affected in glacial environments, were of the extremely angular form with sharp edges, they had high relief and adhering particles (Krinsley \& Doornkamp, 1973). Moreover, microstructures of great variability in size such as conchoidal fractures, arc-shaped steps, linear steps, subparallel linear steps, chattermarks, straight groove, curved groove were founded on the quartz surface as well (Krinsley \& 
Fig. 4. Percentage frequency of occurrence of microstructures linked to chemical weathering. Numerals denote sample numbers (see Fig. 1B).

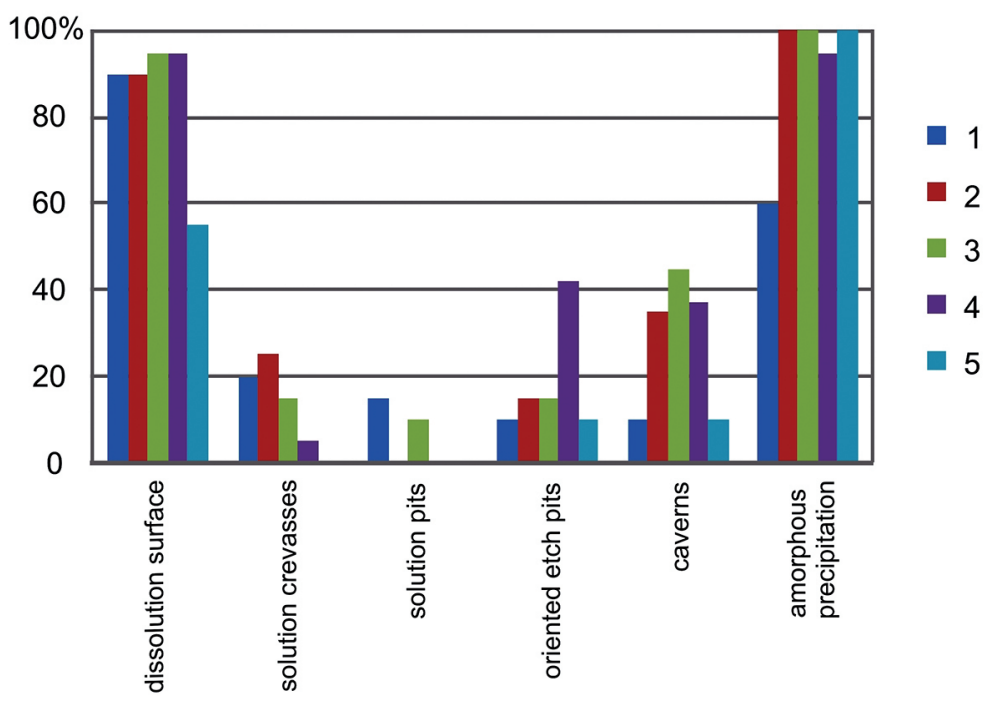

Fig. 5. Percentage frequency of occurrence of microstructures linked to crushing. Numerals denote sample numbers (see Fig. 1B).

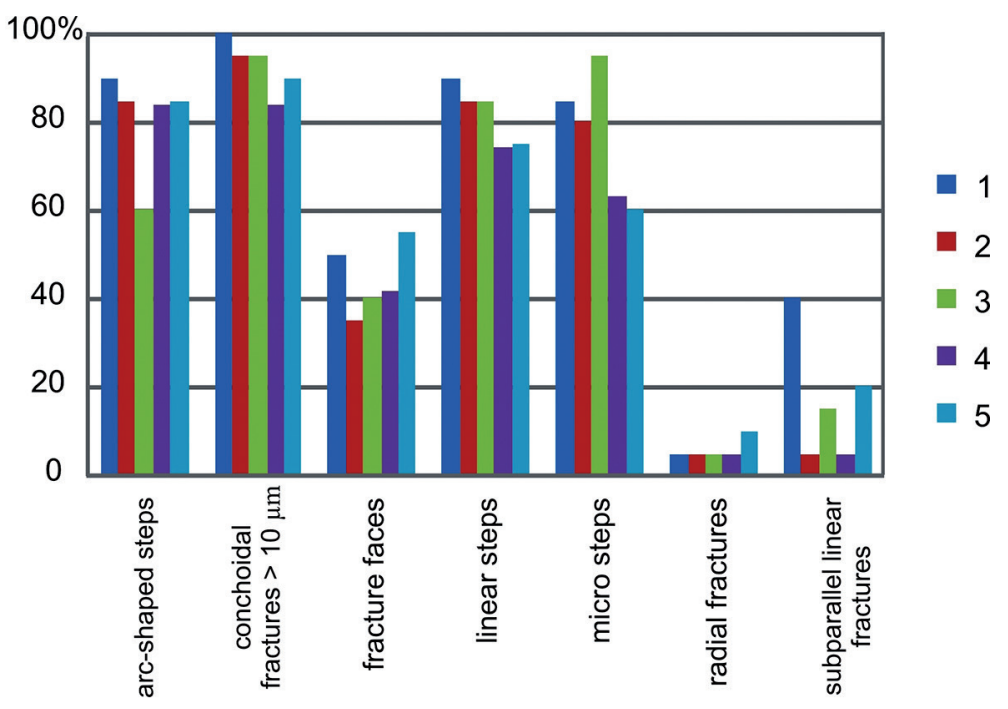

Fig. 6. Percentage frequency of occurrence of microstructures linked to abrasion. $\mathrm{Nu}-$ merals denote sample numbers (see Fig. 1B).

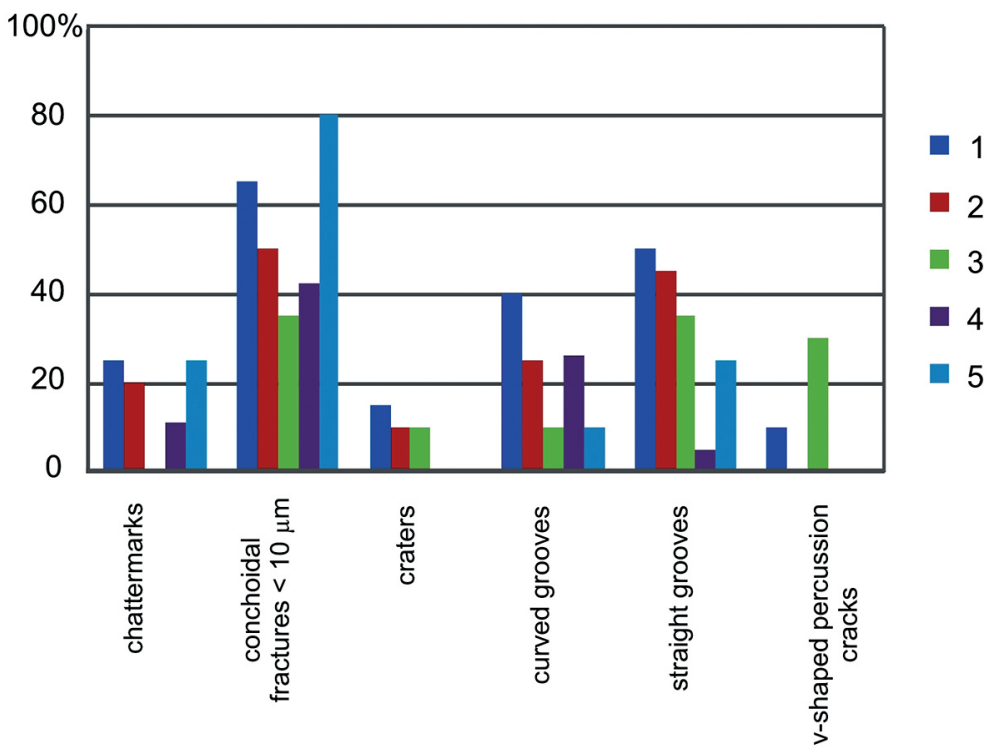



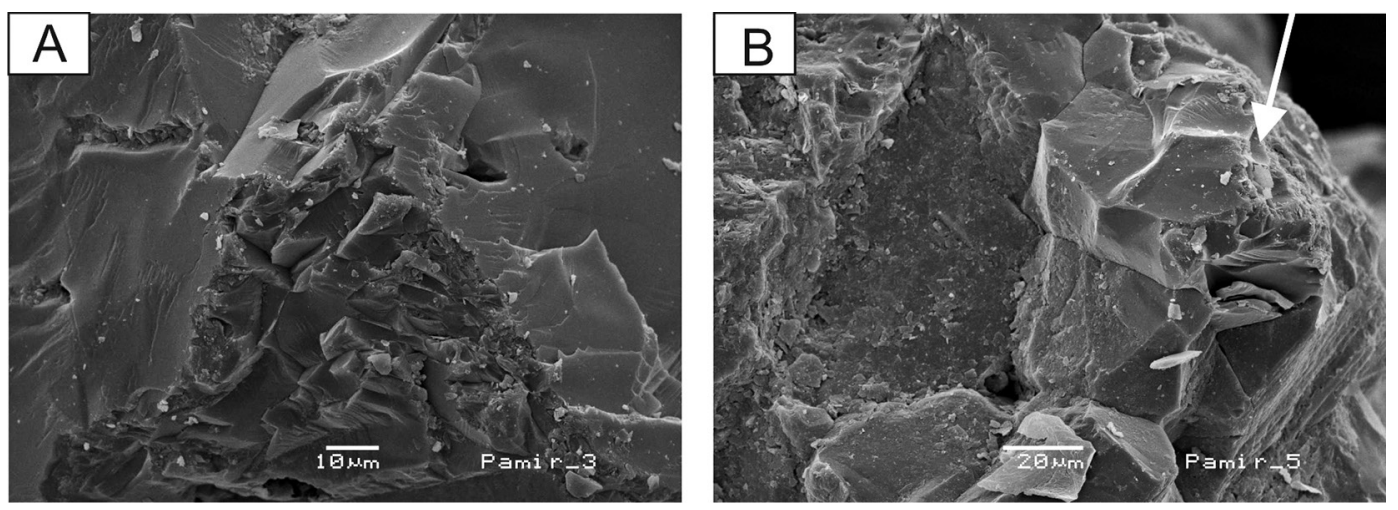

Fig. 7. A - Breakage blocks caused by frost weathering (sample 3); B - Frost weathering on edges of grain (white arrow; sample 5).

Doornkamp, 1973; Tulaczyk et al., 1998; Mahaney et al., 2001; Mahaney, 2002; Rose \& Hart, 2007). Mahaney (2002) emphasised that the most characteristic microstructures of glacial environments were chattermarks, being an effect of plugging. Most of the microstructures were created during grain-tograin contact or grain to glacier bed (Mahaney et al., 2001). However, Sharp \& Gomez (1986) pointed at the presence of not rounded quartz grains with sharp features and fresh surface and they were also formed in passive transport, and they could not connect to processes operating in glacial environments. Therefore, features of grains believed to have come from glacial environments may also have been derived from a former environment and might have been created during mechanical weathering in situ (Sharp \& Gomez, 1986).

Results of my examinations of sediments from Medvezhiy Glacier do not hint at a key role of the glacial environment in the formation of quartz grain surfaces. This is supported by the fact that most of particles analysed are very little effects of crushing and abrasion. In contrast, they dominate the microstructure being the effect of chemical weathering. Results of Cailleux's (1942) analysis clearly showed that percentages of fresh grains of type NU were very low $(<20 \%)$. Additionally, numbers of crushed grains (C) were also low, whereas numbers of weathered grains in situ (OTHER) varied between 39 and $81 \%$ (Table 1). Moreover, the surface of the large conchoidal fractures $(>10 \mu \mathrm{m})$ was almost flat without additional microstructures. It suggests that they were created by weathering in situ outside of a glacial environment, e.g., by frost weathering (Woronko, 2012; Woronko \& Pisarska-Jamroży, in press).

A micromorphological analysis of quartz grain surfaces in surging-glacier deposits was carried out for Gåsbreen, Spitsbergen, by Kenig (1980) and for Briksdalbreen, Norway, by Hart (2006). In both cas- es samples contained large amounts of grains with sharp, very often fresh features and they were characterised by high and medium relief. In the majority of them different sizes of conchoidal fractures were observed, occasionally with a surface with smaller step forms - linear steps, micro steps and arcshaped steps. However, equally common are grains with features that are not connected with abrasion in a glacial environment. Common features of the grains were breakage blocks $>10 \mu \mathrm{m}$, which were created during the phase of grain separation from the host rock or during thermal changes in the glacier's foreland. These authors agreed on the lack of features pointing at any environment and process dominating in the formation of quartz grain surfaces transported in surging glaciers. Kenig (1980) stressed the short time and low intensity of mechanical processes in such environments, while Hart (2006) emphasised the role of grain rotation during transport.

Results obtained clearly show that there are no specific microstructures on the surface of sand quartz grains transported in the surging glaciers. Indeed, it can be noted that the amount of microstructures resulting from abrasion or crushing is very small and limited to conchoidal fractures of different size.

\subsection{Conditions in the surging Medvezhiy glacier}

In all samples examined, the number of microforms caused by abrasion (chattermarks, curved grooves and straight grooves) was much lower than that of the ones formed by crushing (arcshaped steps, conchoidal fractures $<10 \mu \mathrm{m}$, linear steps, micro steps, radial fractures) (Figs. 5, 6). All microforms caused by abrasion were most commonly registered on grain edges, which results 
from mutual tension either amongst particles or between particles and the bed during glacial transport (Sharp \& Gomez, 1986). The predominance of microforms caused by crushing over those caused by abrasion may be connected to the fact that during a surge, the changing pressure in pore-water influences the strain and intensive fragmentation of the material. According to Mahaney (1995) fracturing and abrasion of quartz sand grains probably occurred in till under both low and high pore water pressure. However, those processes were most predominant in till when pore water pressure was low, which permitted grain-to-grain contact. Probably both processes form an erosional continuum, i.e. occur simultaneously or directly after each other (Iverson et al., 1995; Hart, 2006; Rose \& Hart, 2007). The number of conchoidal fractures $>10 \mu \mathrm{m}$ with diverse microtexture may denote a vibrating movement of grains (Mahaney 2002), which takes place due to the high pressure of pore water. Observations carried out during the active phase of surge show that the rapid movement of ice occurs in the basal part of the glacier. Increased ice flow velocity during a surge is triggered by water trapped in glaciers and changes their pressure, which can play a key role in instabilities that cause the activation of surges (Clarke et al., 1984).

Results of an analysis of rounding and frosting of quartz grains (0.8-1.0 mm) by Cailleux (1942) show the grains of the type "OTHER" were the commonest and reveal features of intensive etching in the form of broad coating. In the case of the sediments from a surging glacier it may be a sign of short-lived transport of the material or it may have resulted from the preserving properties of the glacial environment. Whalley \& Krinsley (1974) claimed that in englacial and subglacial environments, in which there were lower concentrations of material, quartz grains did not undergo significant changes. A considerably large number of cracked grains (C) were created probably during the process of separation from the host rock. To a smaller extent they were the result of the grains crushing into each other during transport in a subglacial environment. Wright (1995), Woronko \& Hoch (2011) and Woronko (2012) connected cracked grains (C) also to frost weathering. Samples 3 and 5 come from sediments from the old moraine, where the influence of postsedimentary processes, such as frost weathering, on the surface of quartz grains could have caused the observed cracks. Moreover, Bennett et al. (2003) believed that on the basis of surging glacier, processes of freezing and thawing occur constantly and the thermal regime of this type of glaciers vary between warm in the active phase and cold after the surge, which also may lead to numerous cracked grains observed in the samples. Fresh grains with sharp features (NU) occurred rarely. They made up a higher percentage of sample 1, only on account of the origin of the material, which was collected from the terminal moraine formed in the 2011 surge. The presence of shiny, rounded grains (EM/EL) in some samples (Table 1) can probably be explained by the material having been delivered from an outcrop of quarzitic sandstone along the western slopes of the valley.

\subsection{Erosional continuum in surge glaciers}

On many quartz grains few cycles of abrasion and crushing were noted which were marked by the presence on a single grain of conchoidal fractures fresh and ones coated by amorphous silica. They had overprinted features. This is because Medvezhiy Glacier surges are characterised by an exceptional regularity. Formation of quartz grain surfaces proceeds depending of consecutive, occasionally repetitive processes. The majority of grains examined showed features of having repetitively undergone individual steps in microtexture formation and under various conditions (overprinting).

The first process which forms the grains is separation from the host rock by mechanical weathering in situ, which is marked by the presence of large breakage blocks $(>10 \mu \mathrm{m})$ or large conchoidal features $(>10 \mu \mathrm{m})$. The next process that formed the surface of quartz grains examined is chemical weathering, which might have occurred even when the grains were still in the weathered rock, during contact with external factors. Signs of chemical weathering can take the form of dissolution or amorphous precipitation. In the sample from the 2011 terminal moraine (sample 1) traces of dissolution were observed - raised between fresh surfaces, which are an effect of the next process - damage in a subglacial environment. Most probably, the weathering had modified the grains for a long time. Corroborating this may be the high percentage of grains that show edge rounding caused by etching or precipitation in samples 2, 3, 4 and 5. Moreover, the high frequency of microforms caused by chemical weathering is directly connected with the high prevalence of pre-weathered elements, which were present in over $95 \%$ of all grains analysed. Thus, it may be assumed that the grains examined were not completely transformed after having entered the glacial environment. In the case of deposits of the surging glacier, a range of microstructures related to chemical weathering can be an indication 

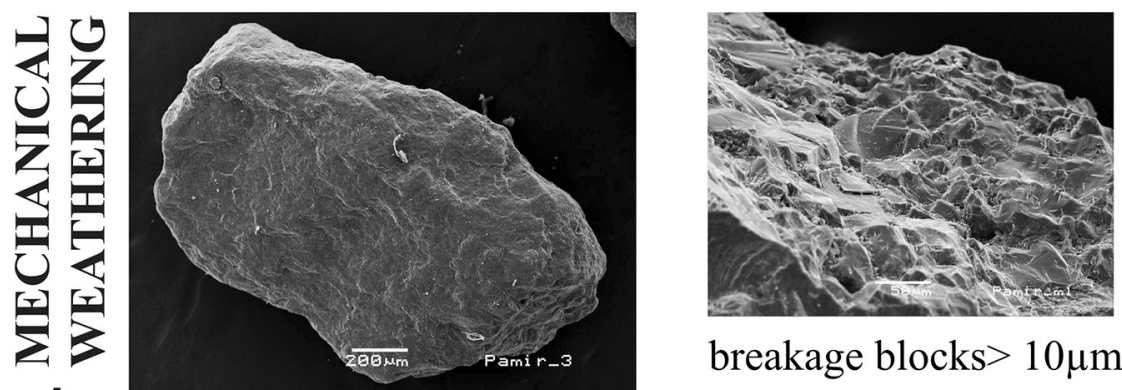

breakage blocks $>10 \mu \mathrm{m}$
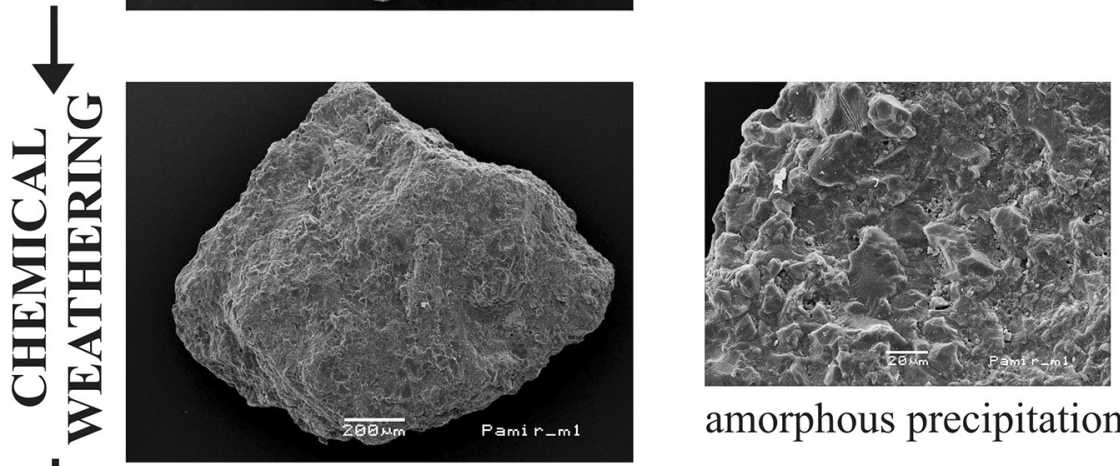

amorphous precipitation
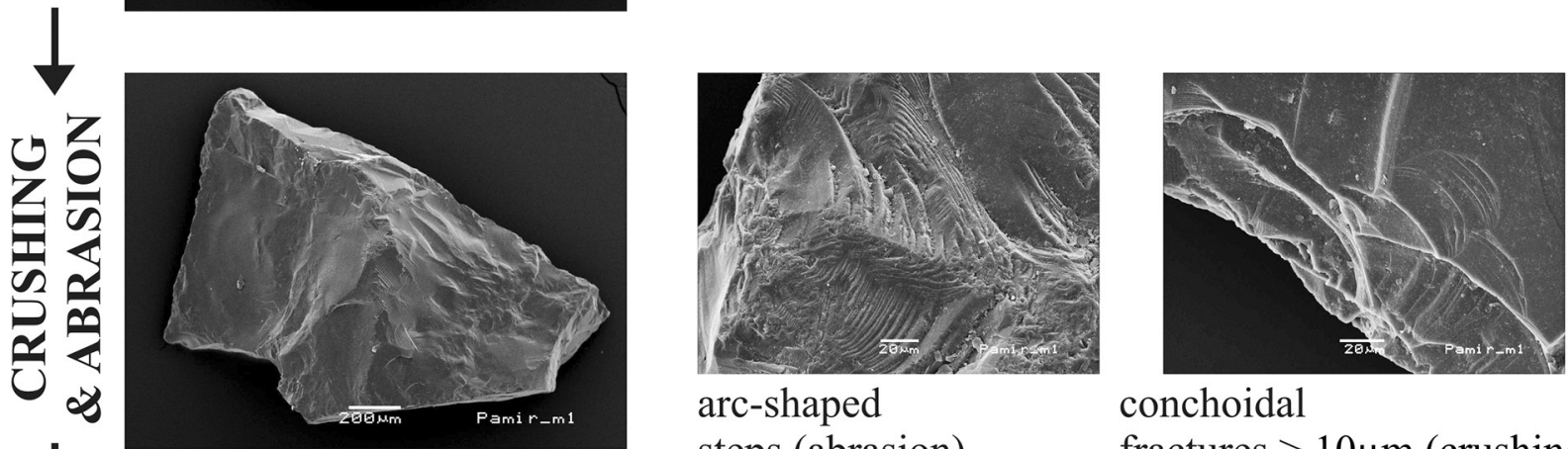

arc-shaped

conchoidal

steps (abrasion)

fractures $>10 \mu \mathrm{m}$ (crushing)

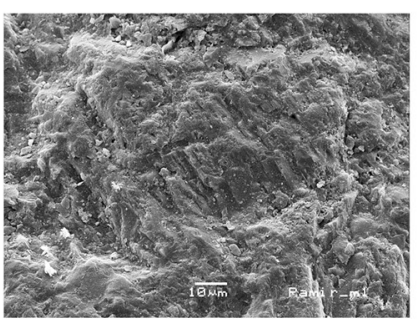

dissolution surface
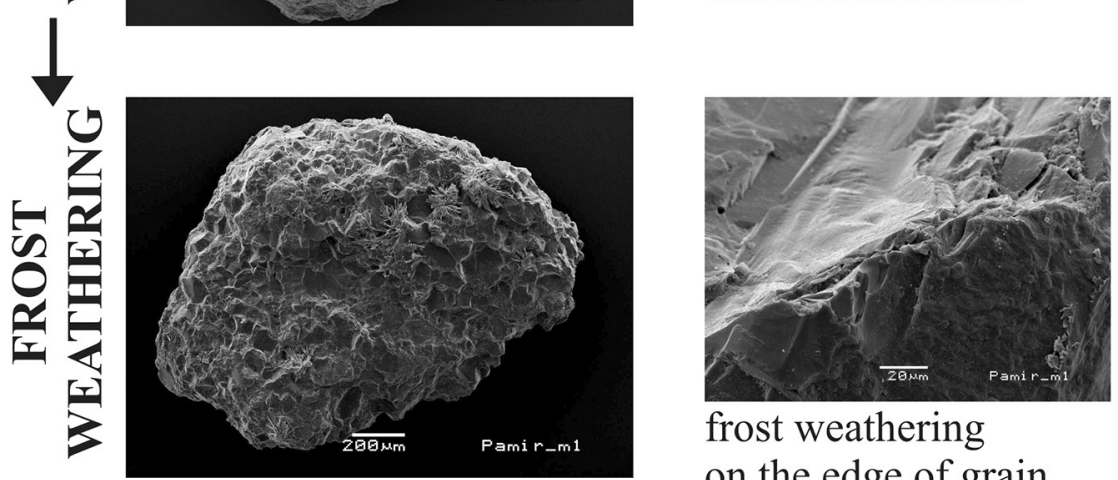

frost weathering on the edge of grain

Fig. 8. Multicycles of shaping quartz grain surfaces. 
of short-lived transport of material in a glacier environment or conditions during glacial transport were not favourable for abrasion or crushing. It can also be a result of the preservational properties of the glacial environment.

At the same time, effects of frost weathering were observed on grain surfaces. Microstructures caused by thermal changes in the environment were examined on previously chemically etched surfaces, on edges of conchoidal fractures $>10 \mu \mathrm{m}$ and on all kinds of microsteps. Also the value of FAI, the determinant of changes in grain surface under the influence of frost weathering, indicates a significant role for freeze-thaw processes in the modelling of grain surfaces. It seems that the older the moraine is, the more advanced frost weathering will be. Frost weathering usually was the last process to form the grain surface. In summary, every grain analysed has undergone a few cycles of processing, which can be seen in Fig. 8 .

\section{Conclusions}

Results of analyses of the micromorphological structure of quartz grain surfaces indicate the limited significance in grain processing of glacial transport in the surge glacier. Grains were affected both by abrasion and crushing. Unfortunately, the outcome does not allow to establish features characteristic of the texture of the surface of quartz grains coming from surging glaciers. However, those processes did not lead to damaging the surface, which had already been shaped by earlier stages of grain formation. Therefore, we may assume that transport was short and of low intensity in damaging processes. In the samples examined, some grains do show the origin of the material in being pre-weathered. What is also worth noting is the significance of the post-sedimentary processes, especially frost weathering, traces of which are visible on most grains.

\section{Acknowledgements}

I thank Mrs B. Woronko for her assistance in elaborating the results and for sharing her knowledge on performing analyses and $\mathrm{Mr}$ A. Stokowski for help during field work.

\section{References}

Benn, D.I. \& Evans, D.J.A., 1998. Glaciers and Glaciation. Arnold, London, 734 pp.
Bennett, M.R., Waller, R.I., Midgley, N.G., Huddart, D., Gonzalez, S., Cook, S.J. \& Tomio, A., 2003.Subglacial deformation at sub-freezing temperatures? Evidence from Hagafellsjokull-Eystri, Iceland. Quaternary Science Reviews 22, 915-923.

Cailleux, A., 1942. Les actionnes éoliennes périglaciaires en Europe. Mémoires de la Société Géologique de France 41, 1-176.

Clarke, G.K.C., 1987. Fast glacier flow: ice streams, surging, and tidewater glaciers. Journal of Geophysca Research 92, 8835-8841.

Clarke, G.K.C., Collins, S.G. \& Thompson, D.E., 1984. Flow, thermal structure, and subglacial conditions of a surge-type glacier. Canadian Journal of Earth Sciences 21, 232-240, 10.1139/e84-024.

Dolgushin, L.D. \& Osipova, G.B., 1975. Glacier surges and the problem of their forecasting. IAHS-AISH Publ. 104, 292-304.

Embleton, C. \& King, C.A.M., 1975. Glacial Geomorphology. Edward Arnold, 1-573

Goździk, J., 1980. Zastosowanie morfoskopii i graniformametrii do badań osadów w kopalni węgla brunatnego „Bełchatów” [Application of morphoscopy and granimormometry for investigations of deposits in the "Bełchatów" brown coal mine]. Studia Regionalne $4,101-114$.

Hart, J.K., 2006. An investigation of subglacial processes at the microscale from Briksdalsbreen. Norway. Sedimentology 53, 125-146.

Helland, P.E. \& Holmes, M.A., 1997. Surface textural analysis of quartz sand grains from ODP Site 918 off the southeast coast of Greenland suggest glaciation of southern Greenland at 11 Ma. Palaeogeography, Palaeoclimatology, Palaeoecology 135, 109-121.

ICIMOD, 2011. Glacial Lakes and Glacial Lake Outburst Floods in Nepal. ICIMOD Books Online, 1-89.

Iverson, N.R., Hanson, B., Hooke, R.L. \& Jansson, P., 1995. Flow mechanics of glaciers on soft beds. Science $267,80-81$.

Kenig, K., 1980. Skład mineralny osadów moreny czołowej lodowca Gås (Spitsbergen) z uwzględnieniem analizy powierzchni ziarn kwarcu w SEM. [Mineral composition of the terminal moraine Gås (Spitsbergen) taking into account the analysis of the surface of the quartz grains in the SEM]. Kwartalnik Geologiczny 24, 711-740.

Kotlyakov, V.M., Osipova, G.B. \& Tsvetkov, D.G., 1997. Fluctuations of unstable mountain glaciers: scale and character. Annals of Glaciology 24, 338-343.

Krinsley, D.H. \& Donahue, J., 1968. Environmental interpretation of sand grain surface textures by electron microscopy. Geological Society of America Bulletin 79, 743-748.

Krinsley, D.H. \& Doornkamp, J.C., 1973. Atlas of Sand Grain Surface Textures. Cambridge University Press, Cambridge, 91-92.

Krumbein, W.C., 1941. Measurement and geological significance of shape and roundness of sedimentary particles. Journal of Sedimentary Petrology 11, 64-72.

Mahaney, W.C., 1990. Macrofabrics and quartz microtextures confirm glacial origin of Sunnybrook drift in the Lake Ontario basin. Geology 19, 145-148. 
Mahaney, W.C., 1995. Pleistocene and Holocene glacier thicknesses and/or transport histories inferred from microtextures and quartz particles. Boreas 24, 293-304.

Mahaney, W.C., 2002. Atlas of sand grain surface textures and applications. Oxford University Press, 26-34.

Mahaney, W.C., Stewart, A. \& Kalm, V., 2001. Quantification of SEM microtextures useful in sedimentary environmental discrimination. Boreas 30, 165-171.

Meier, M.F. \& Post, A., 1969. What are glacier surges? Canadian Journal of Earth Sciences 6, 807-817.

Murray, T., Strozzi, T., Luckman, A., Jiskoot, H. \& Christakos, P., 2003. Is there a single surge mechanism? Contrasts in dynamics between glacier surges in Svalbard and other regions. Journal of Geophysical Research Solid Earth 108, 2237-2252.

Mycielska-Dowgiałło, E. \& Woronko, B., 1998. Analiza obtoczenia i zmatowienia powierzchni ziarn kwarcowych frakcji piaszczystej i jej wartość interpretacyjna [Rounding and frosting analysis of quartz sand-grain surfaces and their interpretative significance]. Przeglad Geologiczny 46, 1275-1281.

Nowikov, V., 2002. Severe hydrometeorological events and their fluctuation. World Meteorological Organization, CBS Technical Conference, $4 \mathrm{pp}$.

Paterson, W.S.B, 1994. The physics of glaciers. Third edition. Pergamon Press, Oxford, 480 pp.

Raymond, C.F., 1987. How do glaciers surge? A review. Journal of Geophysical Research 92, 9121-9134.

Rose, K.C. \& Hart, J.K., 2007. Subglacial comminution in the deforming bed: Inferences from SEM analysis. Sedimentary Geology 203, 87-97.

Sharp, M. \& Gomez, B., 1986. Processes of debris comminution in the glacial environment and implications of quartz sand-grain micromorphology. Sedimentary Geology 46, 33-47.
Traczyk, A. \& Woronko, B., 2010. Historia zlodowacenia doliny Łomnicy $\mathrm{w}$ Karkonoszach $\mathrm{w}$ zapisie mikromorfologii powierzchni ziarn kwarcu [The history of glaciation of the Łomnica Valley in Karkonosze as shown by the quartz grain surface micromorphology records]. Przeglad Geologiczny 58, 1182-1191.

Tulaczyk, S., Kamb, B., Scherer, R. \& Engelhardt, H.F., 1998. Sedimentary processes at the base of a West Antarctic ice stream: constraints from textural and compositional properties of subglacial debris. Journal of Sedimentary Research 68, 487-496.

Whalley, W.B. \& Krinsley, D.H., 1974. Scanning electron microscope study of surface textures of quartz grains from glacial environments. Sedimentology 21, 87-105.

Whalley, W.B. \& Langway, C.C. Jr, 1980. A scanning electron microscope examination of subglacial quartz grain from Camp Century core, Greenland - a preliminary study. Journal of Glaciology 25, 125-131.

Woronko, B., 2012. Micromorphology of quartz grains as a tool in the reconstruction of periglacial environment. [In:]: P. Churski (Ed.): Contemporary issues in Polish geography, Bogucki Wydawnictwo Naukowe, Poznań, 111-131.

Woronko, B. \& Hoch, M., 2011. The Development of Frost-weathering Microstructures on Sand-sized Quartz Grains: Examples from Poland and Mongolia. Permafrost and Periglacial Processes 22, 214-227.

Wright, J.S., 1995. Glacial comminution of quartz sand grains and the production of loessic silt: a simulation study. Quaternary Science Review 14, 669-680.

Zabirow, R.D., 1955. Oledjenienie Pamira [Glaciation of Pamir]. Geograph-GIZ Publisher, Moscow, 372

Manuscript submitted 7 February 2015 Revision accepted 2 May 2015 